\title{
PENGARUH KUALITAS PRODUK, KUALITAS PELAYANAN DAN KEPERCAYAAN TERHADAP LOYALITAS PELANGGAN (Studi pada Konsumen Klinik Erha di Malang)
}

\author{
Amalia Reva Alviska \\ Department of Management FEB UMM \\ E-mail: amaliarevaalviska19@gmail.com
}

\begin{abstract}
This study aimed at analyzing and testing the effect of product and service quality and trust over consumers of Erha Clinic Malang. Method applied in this study was by survey. The analysis tool was double linear regression and hypothetical test by using t-test. Result of the study showed that the product and service quality and trust had a partial effect on consumer loyalty. Based on result and discussion of the study, it was concluded that the performance, endurance, attraction and quality being perceived affected significantly toward the consumers' loyalty. While the physical evidence, reliability, responsiveness, assurance and empathy effected significantly toward the consumers' loyalty. The goodness, competence had significant effect toward the loyalty of Erha Clinic Malang.
\end{abstract}

Keywords: clinic, trust, service quality, product quality, consumers' loyalty

\section{PENDAHULUAN}

Konsumen dan pelanggan merupakan mitra utama bagi pemasar. Pelanggan (Customer) berbeda dengan konsumen (Consumer), seseorang dapat dikatakan sebagai pelanggan apabila orang tersebut mulai membiasakan diri untuk membeli produk atau jasa yang ditawarkan oleh badan usaha. Kebiasaan tersebut dapat dibangun melalui pembelian berulang dalam jangka waktu tertentu, apabila dalam jangka waktu tertentu tidak melakukan pembelian ulang maka orang tersebut tidak dapat dikatakan sebagai pelanggan tetapi sebagai seorang pembeli (Griffin, 2003).

Terdapat beberapa keuntungan strategik bagi perusahaan tentang pentingnya mempertahankan loyalitas pelanggan. Imbalan dari loyalitas bersifat jangka panjang dan kumulatif. Jadi semakin lama loyalitas seorang konsumen, semakin besar laba yang dapat diperoleh perusahaan dari seorang konsumen (Griffin, 2003).

Banyak alasan yang mendorong wanita untuk melakukan perawatan kecantikan. Hasil dari survei yang diadakan oleh Independent Research Agency Taylor Nelson Sofres (TNS) kepada 1800 wanita berusia 20-39 tahun di lima negara Asia: India, Indonesia, Korea, Filipina, dan Thailand dinyatakan bahwa mayoritas wanita Asia (65\%) yakin kulit yang tampak awet muda sangat penting untuk melakukan perawatan kecantikan kulit, wanita Asia mulai melihat tanda-tanda penuaan pada usia rata-rata 25 tahun 7 bulan. Hasil survei mengungkapkan bahwa alasan 
responden ingin menggunakan produk perawatan kecantikan sekitar $66,35 \%$ dari jumlah responden, selanjutnya usia mulai menggunakan produk perawatan kecantikan pada umur 15-20 tahun ada sekitar $46,43 \%$, rata responden menyadari tanda penuaan dini pada umur 25-30 tahun ada sekitar 57,07\%, hampir kebanyakan responden menginginkan perawatan kombinasi (mendapat kulit cerah \& anti-aging) sekitar 63,53\%.

Fenomena tersebut mendukung munculnya banyak klinik-klinik kecantikan yang menawarkan produk dan jasanya untuk memenuhi kebutuhan masyarakat akan perawatan kecantikan. Klinik kecantikan yang muncul saat ini tidak hanya menawarkan jasa perawatan yang dapat dilakukan konsumen saat berada di klinik saja, akan tetapi juga menawarkan produk sebagai kelanjutan dari perawatan yang dilakukan di klinik agar konsumen mendapatkan hasil sesuai dengan yang diinginkannya. Salah satu skin care yang terkenal di Kota Malang adalah Erha Clinic.

Produk dari Erha Clinic merupakan formula para ahli dermatologi yang dihasilkan dari penelitian berbasis pharmaceutical science dan technology sehingga terapi dan obat yang diberikan pun terjamin aman karena formulasi terbaik yang dikembangkan oleh pusat riset dan pengembangan produk oleh Erha Laboratory.

Erha Clinic memberikan pelayanan jasa di bidang Cosmetic Dermatology yang meliputi Rejuvenation Center, Anti Acne Center, Hair Center, Body Center dan General Dermatology (kasus kulit umum) yang meliputi Children's Skin Center (kasus kulit anak), Senior's Skin Center (kasus kulit orang tua) dan Special Skin Center. Erha Clinic berkomitmen untuk memberikan yang terbaik dalam hal dermatologi. Respon positif dari pelanggan akan perawatan kulit membuat Erha Clinic berkembang pesat. Cabang Erha Clinic tersebar di seluruh kota besar di Indonesia dengan jumlah lebih dari 60 cabang dilengkapi dengan teknologi terkini dan ditangani oleh para dermatologist yang tersertifikasi.

Erha Clinic juga meraih Top Brand Awards Index dari tahun ke tahun yang posisinya menempati posisi kedua dari pesaingnya. Pencapaian Top Brand tersebut dapat dilihat pada Tabel 1 sebagai berikut:

Tabel 1. Top Brand Awards Index Kategori Klinik Kecantikan Periode 2013-2015

\begin{tabular}{lcccc}
\hline Merek & TBI & TBI & TBI & \multirow{2}{*}{ TOP } \\
& $(2013)$ & $(2014)$ & $(2015)$ & \\
\hline Natasha & $35,0 \%$ & $34,9 \%$ & $26,1 \%$ & TOP \\
Erha & $14,2 \%$ & $17,1 \%$ & $21,8 \%$ & TOP \\
Miracle & $6,5 \%$ & $2,5 \%$ & $4,8 \%$ & \\
LBC & $3,0 \%$ & $5,1 \%$ & $3,5 \%$ & \\
Dr. Eva & - & $2,8 \%$ & $5,1 \%$ & \\
Estestika & - & $2,6 \%$ & $3,1 \%$ & \\
\hline
\end{tabular}

Berdasarkan Tabel. 1 menunjukan data Top Brand kategori klinik kecantikan/perawatan kulit dari tahun 2013 sampai dengan tahun 2015. Pada tahun 2013 persentase Erha Clinic mendapatkan hasil $14.2 \%$, kemudian pada tahun 2014 mengalami kenaikan sebesar $2.9 \%$ menjadi $17.1 \%$, dan pada tahun berikut mengalami kenaikan sebesar 4.7\% menjadi $21.8 \%$. Persentase tersebut menunjukan bahwa Erha 
Clinic terus mengalami kemajuan dengan kenaikan angka TBI. Salah satu yang mungkin menyebabkan angka TBI yang terus meningkat adalah kualitas produk, kualitas layanan, dan kepercayaan pelanggan.

Tabel 2 menunjukan jumlah pengunjung dalam tiga tahun terakhir. Hal tersebut menggambarkan bahwa Erha Clinic di Kota Malang memiliki jumlah pengunjung yang terus meningkat dari tahun ke tahun. Peningkatan tersebut selaras dengan TBI, ini mengindikasikan bahwa Erha Clinic memiliki kinerja pemasaran yang baik dan tentunya berpengaruh positif kepada keberlangsungan perusahaan. Data pengunjung klinik kecantikan Erha dalam tiga tahun terakhir dapat dilihat pada Tabel 2 sebagai berikut:

Tabel 2. Data Pengunjung Erha Clinic Selama 3 tahun

\begin{tabular}{lccc}
\hline \multicolumn{1}{c}{ Bulan } & 2013 & 2014 & 2015 \\
\hline Januari & 301 & 413 & 465 \\
Februari & 268 & 370 & 478 \\
Maret & 337 & 345 & 441 \\
April & 364 & 348 & 515 \\
Mei & 348 & 405 & 489 \\
Juni & 326 & 453 & 466 \\
Juli & 347 & 446 & 554 \\
Agustus & 361 & 438 & 536 \\
September & 352 & 487 & 565 \\
Oktober & 407 & 486 & 543 \\
November & 365 & 498 & 574 \\
Desember & 364 & 473 & 539 \\
\hline Total & 4.140 & 5.162 & 6.165 \\
\hline
\end{tabular}

Tabel 2 menunjukan peningkatan yang cukup besar sekitar 1000 pelanggan baru. Pada tahun 2013, pengunjung Erha Clinic 4.140, sedangkan pada tahun 2014 meningkat 1022 menjadi 5.162 pelanggan, dan pada tahun 2015 meningkat 1003 menjadi 6.165 pelanggan.
Berdasarkan top brand index dan data pertumbuhan pengunjung, maka penelitian ini akan menguji variabel terkait loyalitas pelanggan yang dilihat dari sudut pandang kualitas produk, kualitas pelayanan, dan kepercayaan.

\section{TINJAUAN PUSTAKA}

Perilaku konsumen merupakan respon psikologis yang kompleks, yang muncul dalam bentuk perilaku tindakan yang khas secara perseorangan yang langsung terlibat dalam usaha memperoleh dan menggunakan produk, serta menentukan proses pengambilan keputusan dalam melakukan pembelian produk, termasuk dalam melakukan pembelian ulang (Hasan, 2009). Menurut Griffin (2003: 31) bahwa pelanggan yang loyal adalah: 1) Melakukan pembelian berulang secara teratur, 2) Membeli antar lini produk dan jasa, 3) Mereferensikan kepada orang lain, 4) Menunjukan kekebalan dari terhadap tarikan dari pesaing.

Menurut Kotler \& Amstrong (2008: 347), kualitas produk adalah kemampuan sebuah produk dalam memperagakan fungsinya, hal itu termasuk durabilitas, reliabilitas, ketepatan, kemudahan pengoperasian dan reparasi produk juga atribut produk lainnya. Dimensi kualitas produk menurut Tjiptono (2008:25) antara lain: 1) Kinerja (Performance), 2) Ciri-ciri atau keistimewaan tambahan (Features), 3) Kesesuaian dengan spesifikasi (Conformance to Spesification), 4) Keandalan (Realibility), 5) Daya tahan (Durability), 6) Estetika (Esthetica), 7) Kualitas yang dipersepsikan (Perceived Quality), 8) 
Dimensi kemudahan perbaikan (Serviceability),

Kualitas pelayanan adalah evaluasi pengamatan jangka panjang konsumen terhadap penyerahan jasa suatu perusahaan (Lovelock \& Wright, 2007: 96). Menurut Tjiptono (2012), terdapat lima dimensi kualitas pelayanan yaitu: 1) Bukti Fisik (Tangible), 2) Keandalan (reliability) 3) Daya Tanggap (responsiveness), 4) Jaminan (assurance), 5) Empati (emphaty).

Kepercayaan konsumen (consumer beliefs) adalah semua pengetahuan yang dimiliki oleh konsumen dan semua kesimpulan yang dibuat konsumen tentang objek, atribut, dan manfaatnya (Mowen, 2002: 312). Adapun dimensi kepercayaan menurut Robbins (2006: 463) ada lima yaitu: 1) Integritas, 2) Kompetensi, 3) Konsistensi, 4) Loyalitas, 5) Keterbukaan.

Hubungan pengaruh kualitas produk, kualitas layanan, dan kepercayaan tterhadap loyalitas pelanggan telah dibuktikan secara empiris oleh penelitian sebagai berikut. Budiman (2006) menemukan bahwa kualitas produk mempunyai pengaruh signifikan terhadap loyalitas pelanggan. Berdasarkan hasil penelitian oleh Hadiyati (2010), kualitas pelayanan ditemukan mempunyai pengaruh signifikan terhadap loyalitas pelanggan. Penelitian oleh Riana (2008) tentang pengaruh trust in $s$ brand terhadap brand loyalty dengan menggunakan alat analisis regresi linier berganda diperoleh bahwa kepercayaan memiliki pengaruh signifikan terhadap brand loyalty.

Berdasarkan pustaka yang telah dijelaskan maka kerangka konseptual dalam penelitian ini dikembangkan seperti Gambar 1 sebagai berikut:

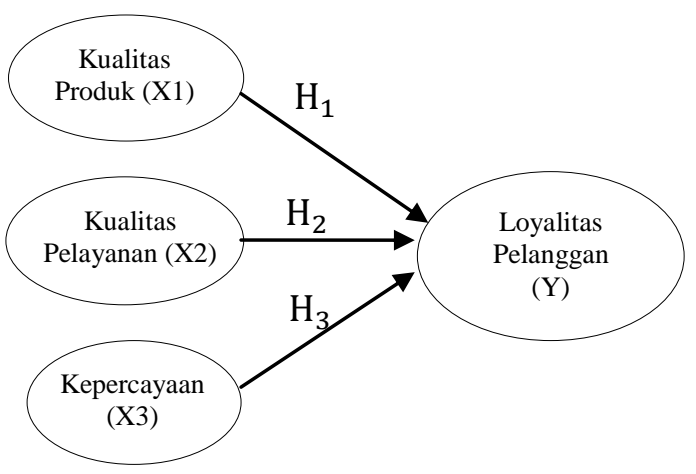

Gambar 1. Kerangka Konseptual

\section{METODE PENELITIAN}

Lokasi penelitian Jalan Bromo Kavling 1-2 Oro-oro Dowo Klojen, Malang, Jawa Timur. Penelitian ini dilakukan dengan survey yang mana informasinya dikumpulkan dengan menggunakan kuesioner.

Populasi pada penelitian ini adalah pelanggan yang menggunakan jasa Erha Clinic Malang. Sampel pada penelitian ini berjumlah 100 responden. Pengambilan sampel yang dilakukan dengan metode nonprobability sampling menggunakan sampling purposive, yaitu teknik penentuan sampel berdasarkan pertimbangan tertentu.

Adapun karakteristik dan syarat yang digunakan dalam pengambilan sampel adalah laki-laki atau perempuan, usia $17-60$ tahun, karakteristik ini diambil dengan alasan pada usia 17 tahun responden sudah mencapai batasan kecukupan usia untuk melakukan perawatan, telah melakukan transaksi pembelian minimal 2 kali pada Erha Clinic. Karakteristik ini diambil dengan alasan bahwa konsumen yang telah melakukan transaksi pembelian sebanyak 2 kali atau lebih, 
cenderung merupakan konsumen yang puas dan melakukan pembelian ulang.

Penelitian ini menggunakan data primer yang diperoleh dari jawaban responden pada kuesioner yang telah disebarkan. Data sekunder merupakan data yang diperoleh tidak secara langsung dari sumbernya, melainkan sudah diolah dan dikumpulkan oleh pihak lain yang mana sebagai sumber informasi. Seperti data hasil survei yang di lakukan sebelumnya oleh Top Brand.

Teknik pengumpulan data yang digunakan dalam penelitian ini adalah metode survei berupa angket atau kuisioner. Teknik pengukuran variabel dalam penelitian ini menggunakan skala iikert lima tingkat.

Pengujian Instrumen pada penelitian ini yaitu, uji validitas adalah uji yang mengukur tingkatantingkatan kevalidan suatu instrumen yang hendak diteliti (Arikunto, 2009: 170). Uji Reliabilitas adalah kepercayaan pada instrumen untuk digunakan sebagai alat pengumpul data karena instrumen tersebut sudah baik (Arikunto, 2009:171).

Teknik Analisis Data yang digunakan pada penelitian ini adalah Analisis regresi linier berganda adalah prosedur statistik untuk menganalisa hubungan antara kualitas produk, kualitas pelayanan, kepercayaan terhadap loyalitas pelanggan (Arikunto, 2009: 374). Koefisien determinasi pada intinya mengukur seberapa jauh kemampuan model dalam menerangkan variasi variabel dependen (Ghozali, 2001: 83). Uji Hipotesis pada menggunakan uji t digunakan untuk menunjukkan apakah suatu variabel kualitas produk, kualitas pelayanan, kepercayaan secara individual mempengaruhi variabel loyalitas pelanggan (Ghozali, 2005: 84).

\section{HASIL DAN PEMBAHASAN}

Untuk mengetahui kualitas produk, kualitas pelayanan, kepercayaan dan loyalitas pelanggan di Erha Clinic Malang maka digunakan distribusi jawaban responden, yaitu sebagai berikut:

Tabel 3. Diskripsi Jawaban

Responden Tentang Variabel Kualitas Produk $\left(\mathrm{X}_{1}\right)$

\begin{tabular}{|c|c|c|c|c|c|}
\hline Item & $\begin{array}{c}\text { SS } \\
\text { F }\end{array}$ & $\begin{array}{l}\mathrm{S} \\
\mathrm{F}\end{array}$ & $\begin{array}{l}\mathrm{N} \\
\mathrm{F}\end{array}$ & $\begin{array}{c}\text { TS } \\
\text { F }\end{array}$ & $\begin{array}{c}\text { STS } \\
\text { F }\end{array}$ \\
\hline$X_{1.1}$ & 32 & 56 & 8 & 4 & 0 \\
\hline $\mathrm{X}_{1.2}$ & 31 & 57 & 9 & 3 & 0 \\
\hline $\mathrm{X}_{1.3}$ & 16 & 68 & 11 & 5 & 0 \\
\hline $\mathrm{X}_{1.4}$ & 25 & 65 & 7 & 3 & 0 \\
\hline
\end{tabular}
diketahui bahwa tanggapan responden terhadap masing-masing item yang ada pada kualitas produk, jawaban terbesar pada $\mathrm{X}_{1.3}$ sebesar 68 responden $(68 \%)$ yaitu produk Erha Clinic tidak berubah warna dalam waktu simpan 1-3 tahun.

Tabel 4. Diskripsi Jawaban Responden Tentang Variabel Kualitas Pelayanan $\left(\mathrm{X}_{2}\right)$

\begin{tabular}{|c|c|c|c|c|c|}
\hline \multirow{2}{*}{ Item } & SS & S & $\mathrm{N}$ & $\mathrm{TS}$ & STS \\
\hline & $\mathrm{F}$ & F & $\mathrm{F}$ & $\mathrm{F}$ & $\mathrm{F}$ \\
\hline $\mathrm{X}_{2.1}$ & 19 & 67 & 11 & 3 & 0 \\
\hline $\mathrm{X}_{2.2}$ & 9 & 81 & 7 & 3 & 0 \\
\hline $\mathrm{X}_{2.3}$ & 12 & 68 & 17 & 3 & 0 \\
\hline $\mathrm{X}_{2.4}$ & 14 & 73 & 10 & 3 & 0 \\
\hline$X_{2.5}$ & 43 & 48 & 6 & 3 & 0 \\
\hline & & & Tabel & 4 & dapat \\
\hline
\end{tabular}
responden terhadap masing-masing item yang ada pada kualitas pelayanan, jawaban terbesar pada $\mathrm{X}_{2.2}$ sebesar 81 responden $(81 \%)$ yaitu Erha Clinic memiliki perawat handal dalam melayani pelanggan. 
Tabel 5. Diskripsi Jawaban

Responden Tentang Variabel

\begin{tabular}{cccccc}
\multicolumn{6}{c}{ Kepercayaan $\left(\mathrm{X}_{3}\right)$} \\
\hline \multirow{2}{*}{ Item } & $\mathrm{SS}$ & $\mathrm{S}$ & $\mathrm{N}$ & $\mathrm{TS}$ & $\mathrm{STS}$ \\
& $\mathrm{F}$ & $\mathrm{F}$ & $\mathrm{F}$ & $\mathrm{F}$ & $\mathrm{F}$ \\
\hline $\mathrm{X}_{3.1}$ & 27 & 70 & 3 & 0 & 0 \\
$\mathrm{X}_{3.2}$ & 42 & 55 & 3 & 0 & 0 \\
$\mathrm{X}_{3.3}$ & 45 & 53 & 2 & 0 & 0 \\
\hline
\end{tabular}

Berdasarkan Tabel 5 dapat diketahui bahwa tanggapan responden terhadap masing-masing item yang ada pada kepercayaan, jawaban terbesar pada $\mathrm{X}_{3.1}$ sebesar 70 responden $(70 \%)$ yaitu karyawan Erha Clinic jujur dalam bertransaksi

Tabel 6. Diskripsi Jawaban Responden Tentang Variabel Loyalitas Pelanggan (Y)

\begin{tabular}{cccccc}
\hline \multirow{2}{*}{ Item } & SS & S & N & TS & STS \\
& F & F & F & F & F \\
\hline $\mathrm{Y}_{1.1}$ & 20 & 17 & 32 & 0 & 0 \\
$\mathrm{Y}_{1.2}$ & 72 & 70 & 65 & 0 & 0 \\
$\mathrm{Y}_{1.3}$ & 8 & 13 & 3 & 0 & 0 \\
\hline
\end{tabular}

Berdasarkan Tabel 6 dapat diketahui bahwa tanggapan responden terhadap masing-masing item yang ada pada loyalitas pelanggan, jawaban terbesar pada $\mathrm{Y}_{1.2}$ sebesar 72 responden (72\%) yaitu pelanggan merekomendasikan teman, saudara, keluarga, dan lainlain untuk melakukan therapy di Erha Clinic.

Uji Validitas pada penelitian ini dengan membandingkan $r_{\text {hitung }}$ dengan $r_{\text {tabel }}$. Apabila hasil $r_{\text {hitung }}>$ $\mathrm{r}_{\text {tabel }}$ (pada taraf signifikan 5\%) maka data tersebut dinyatakan valid. Penelitian ini menggunakan 100 sampel dengan nilai $r_{\text {tabel }} 0,197$. Hasil uji validtas untuk masing-masing variabel penelitian dapat dilihat pada Tabel 7 berikut ini:
Tabel 7. Hasil Uji Validitas

\begin{tabular}{cccc}
\hline $\begin{array}{c}\text { Kualitas } \\
\text { Produk }\left(\mathrm{X}_{1}\right)\end{array}$ & $\mathrm{r}_{\text {hitung }}$ & $\mathrm{r}_{\text {tabel }}$ & Keterangan \\
\hline $\mathrm{X}_{1.1}$ & 0,872 & 0,197 & Valid \\
$\mathrm{X}_{1.2}$ & 0,924 & 0,197 & Valid \\
$\mathrm{X}_{1.3}$ & 0,910 & 0,197 & Valid \\
$\mathrm{X}_{1.4}$ & 0,863 & 0,197 & Valid \\
\hline Kualitas & & & \\
$\begin{array}{c}\text { Pelayanan } \\
\left(\mathrm{X}_{2}\right)\end{array}$ & $\mathrm{r}_{\text {hitung }}$ & $\mathrm{r}_{\text {tabel }}$ & Keterangan \\
\hline $\mathrm{X}_{2.1}$ & 0,889 & 0,197 & Valid \\
$\mathrm{X}_{2.2}$ & 0,876 & 0,197 & Valid \\
$\mathrm{X}_{2.3}$ & 0,861 & 0,197 & Valid \\
$\mathrm{X}_{2.4}$ & 0,897 & 0,197 & Valid \\
$\mathrm{X}_{2.5}$ & 0,836 & 0,197 & Valid \\
\hline Kepercayaan & $\mathrm{r}_{\text {hitung }}$ & $\mathrm{r}_{\text {tabel }}$ & Keterangan \\
$\left(X_{3.3}\right)$ & 0,830 & 0,197 & Valid \\
\hline $\mathrm{X}_{3.1}$ & 0,909 & 0,197 & Valid \\
$\mathrm{X}_{3.2}$ & 0,899 & 0,197 & Valid \\
$\mathrm{X}_{3.3}$ & $\mathrm{r}_{\text {hitung }}$ & $\mathrm{r}_{\text {tabel }}$ & Keterangan \\
\hline Loyalitas $(Y)$ & 0,898 & 0,197 & Valid \\
\hline $\mathrm{Y}_{1.1}$ & 0,909 & 0,197 & Valid \\
$\mathrm{Y}_{1.2}$ & 0,804 & 0,197 & Valid \\
$\mathrm{Y}_{1.3}$ & & & \\
\hline
\end{tabular}

Tabel 7 menunjukan bahwa semua item yang digunakan untuk mengukur variabel dalam penelitian ini adalah valid atau tepat untuk mengukur variebel yang diteliti.

Uji Reliabilitas merupakan uji keandalan suatu instrument pengumpulan data. Uji reliabilitas dikatakan reliabel apabila nilai Cronbach's Alpha lebih dari 0,6 maka butir pernyataan yang diberikan pada kuesioner bersifat reliabel. Hasil uji reliabilitas ditunjukkan oleh Tabel 8 berikut ini:

Tabel 8. Hasil Uji Reliabilitas

\begin{tabular}{lcc}
\hline \multicolumn{1}{c}{ Variabel } & $\begin{array}{c}\text { Nilai } \\
\text { Cronbach's } \\
\text { Alpha }\end{array}$ & $\begin{array}{c}\text { Cronbach's } \\
\text { Alpha }\end{array}$ \\
\hline $\begin{array}{l}\text { Kualitas Produk } \\
\text { Kualitas }\end{array}$ & 0,914 & 0,6 \\
$\begin{array}{l}\text { Pelayanan } \\
\text { Kepercayaan }\end{array}$ & 0,917 & 0,6 \\
$\begin{array}{l}\text { Loyalitas } \\
\text { Pelanggan }\end{array}$ & 0,854 & 0,6 \\
\hline
\end{tabular}


Berdasarkan Tabel 8 menunjukan bahwa semua variabel kualitas produk, kualitas pelayanan, kepercayaan dan loyalitas adalah reliabel, hal ini dikarenakan nilai Cronbach's alpha lebih besar dari 0,6 .

Analisis regresi linier berganda digunakan untuk mengetahui sejauh mana besarnya pengaruh kualitas produk, kualitas pelayanan dan kepercayaan terhadap loyalitas pelanggan yang dilakukan dengan menggunakan aplikasi SPSS didapatkan persamaan regresi linier berganda, $Y=3,635+0,097+$ $0,112+0,380$

Dari persamaan regresi di atas dapat dijelaskan bahwa konstanta (nilai a) sebesar 3,635 menunjukan jika semua variabel bebas (kualitas produk, kulalitas pelayanan, kepercayaan) memiliki nilai nol maka loyalitas pelanggan (Y) akan memiliki nilai sebesar 3,635.

Pengaruh Kualitas Produk $\left(\mathrm{X}_{1}\right)$ terhadap loyalitas pelanggan (Y) bernilai positif sebesar 0,097 , artinya setiap adanya peningkatan pada kualitas produk $\left(\mathrm{X}_{1}\right)$ maka loyalitas pelanggan (Y) akan ikut meningkat dengan asumsi variabel lain konstan.

Pengaruh Kualitas Pelayanan $\left(\mathrm{X}_{2}\right)$ terhadap loyalitas pelanggan (Y) bernilai positif sebesar 0,112 , artinya setiap adanya peningkatan pada kualitas pelayanan $\left(\mathrm{X}_{2}\right)$ maka loyalitas pelanggan (Y) akan ikut meningkat dengan asumsi variabel lain konstan.

Pengaruh Kepercayaan $\left(\mathrm{X}_{3}\right)$ terhadap loyalitas pelanggan (Y) bernilai positif sebesar 0,380 , artinya setiap adanya peningkatan pada kepercayaan $\left(\mathrm{X}_{3}\right)$ maka loyalitas pelanggan (Y) akan ikut meningkat dengan asumsi variabel lain konstan.

Uji $t$ ini digunakan untuk menunjukan apakah suatu variabel kualitas produk, kualitas pelayanan, kepercayaan secara individual mempengaruhi loyalitas pelanggan. Berdasarkan hasil olah data dengan program SPSS menggunakan regresi linier berganda diperoleh hasil uji $\mathrm{t}$ untuk masing masing variabel bebas dapat dilihat pada Tabel 9 sebagai berikut:

Tabel 9. Hasil Uji t

\begin{tabular}{lccl}
\hline \multicolumn{1}{c}{ Variabel } & T hitung & T tabel & Keterangan \\
\hline Kualitas & 2,065 & 1,985 & Ha \\
$\begin{array}{l}\text { Produk } \\
\text { Kualitas }\end{array}$ & 2,377 & 1,985 & Diterima \\
$\begin{array}{l}\text { Pelayanan } \\
\text { Kepercayaan }\end{array}$ & 4,133 & 1,985 & Diterima \\
& & & Ha \\
& & Diterima \\
\hline
\end{tabular}

Berdasarkan hasil olah data pada Tabel 9 dengan program SPSS menggunakan regresi linier berganda diperoleh hasil uji $\mathrm{t}$ untuk masing masing variabel bebas adalah sebagai berikut, kualitas produk $\left(\mathrm{X}_{1}\right)$ diperoleh $t_{\text {hitung }}$ sebesar 2.065 dan $\mathrm{t}_{\text {tabel }}$ sebesar 1,985 dengan tingkat signifikansi 0,042. Karena $\mathrm{t}_{\text {hitung }}>$ $\mathrm{t}_{\text {tabel }}(2.065>1,985)$ dan signifikansi lebih kecil dari $0,05(0,042<0,05)$ maka Ha yang berbunyi kualitas produk $\left(\mathrm{X}_{1}\right)$ berpengaruh secara signifikan terhadap loyalitas pelanggan (Y) diterima.

Kualitas pelayanan $\left(\mathrm{X}_{2}\right)$ diperoleh $\mathrm{t}_{\text {hitung }}$ sebesar 2.377 dan $\mathrm{t}_{\text {tabel }}$ sebesar 1,985 dengan tingkat signifkansi 0,019 . Karena $t_{\text {hitung }}>t_{\text {tabel }}(2.377>$ 1,985) dan signifikansi lebih kecil dari $0,05(0,019<0,05)$ maka $\mathrm{Ha}$ yang berbunyi kualitas pelayanan $\left(\mathrm{X}_{2}\right)$ berpengaruh terhadap loyalitas pelanggan $(\mathrm{Y})$ diterima. 
Kepercayaan $\left(\mathrm{X}_{3}\right)$ diperoleh $\mathrm{t}_{\text {hitung }}$ sebesar 4.133 dan $\mathrm{t}_{\text {tabel }}$ sebesar 1,985 dengan tingkat signifikansi sebesar 0,000 . Karena $t_{\text {hitung }}>t_{\text {tabel }}$ $(4.133>1,985)$ dan signifikan lebih kecil dari $0,05(0,000<0,05)$ maka $\mathrm{Ha}$ berbunyi kepercayaan $\left(\mathrm{X}_{3}\right)$ berpengaruh tsecara signifikan terhadap loyalitas pelanggan $(\mathrm{Y})$ diterima.

Berdasarkan hasil olah data dengan program SPSS menggunakan regresi linier berganda diketahui bahwa koefisien determinasi (Adjusted R Square) di peroleh hasil sebesar 0,309. Hal ini berarti 30,9\% variabel loyalitas pelanggan dapat dijelaskan oleh variabel kualitas produk, kualitas pelayanan, kepercayaan pelanggan, sedangkan $69,1 \%$ dijelaskan oleh variabel lain yang tidak terdapat dalam penelitian ini.

\section{PEMBAHASAN}

Hasil penelitian ini mendukung penelitian sebelumnya yang dilakukan Budiman (2006) diperoleh bahwa kualitas produk berpengaruh secara signifikan terhadap loyalitas pelanggan.

Pengaruh Kualitas Pelayanan terhadap Loyalitas Pelanggan. Hasil penelitian ini mendukung penelitian sebelumnya yang dilakukan Hadiyati (2010) diperoleh bahwa kualitas pelayanan berpengaruh secara signifikan terhadap loyalitas pelanggan

Pengaruh Kepercayaan terhadap Loyalitas Pelanggan. Hasil penelitian ini mendukung penelitian sebelumnya yang dilakukan Riana (2008) diperoleh bahwa kepercayaan berpengaruh secara signifikan terhadap loyalitas pelanggan.

\section{KESIMPULAN}

Berdasarkan hasil penelitian dan pembahasan yang telah dilakukan maka dapat diperoleh kesimpulan sebagai berikut. Kinerja, daya tahan, daya tarik dan kualitas yang dipersepsikan (perceived quality) berpengaruh secara signifikan terhadap loyalitas pelanggan Erha Clinic Malang.

Bukti fisik, keandalan, daya tanggap, jaminan dan empati berpengaruh secara signifikan terhadap loyalitas pelanggan Erha Clinic Malang. Integritas, kebaikan dan kompetensi berpengaruh secara signifikan terhadap loyalitas pelanggan Erha Clinic Malang.

\section{SARAN}

Berdasarkan hasil penelitian dan pembahasan yang telah dilakukan maka dapat diajukan saran sebagai beriku, bagi Perusahaan Erha Clinic Perusahaan Erha Clinic perlu meningkatkan kualitas produk dengan menciptakan produk perawatan kulit yang memadukan keahlian dermatologist yang berpengalaman dan pemahaman akan perbedaan kebutuhan masing-masing individu seperti mengatasi persoalan kulit wajah seperti jerawat, penuaan kulit ataupun permasalahan kulit lainnya semakin baik produk bisa mengatasi permasalahan kulit wajah semakin banyak orang yang akan melakukan pembelian ulang dan merekomendasikan ke orang lain dikarenakan hasil yang sesuai dengan keinginan pelanggan disertai keamanan produk sehingga terhindar dari bahaya iritasi, pembengkakan pada wajah dan alergi.

Untuk meningkatkan kualitas pelayanan karyawan harus lebih 
tanggap dalam menghadapi keluhan pelanggan. Sambutan dari karyawan yang ramah, sikap profesionalisme karyawan dapat membuat pelanggan mendapatkan kesan menyenangkan dari pertama berkunjung hingga akhir kunjungan.

Reputasi perusahaan harus terus diperhatikan karena merupakan nilai tambah bagi Erha Clinic agar setiap langkah yang diambil di setiap perawatan dapat dipertanggungjawabkan dan menambah kepercayaan pelanggan kepada Erha Clinic, karena klinik kecantikan kulit yang baik adalah memiliki dokter ahli bidang dermatologi dilengkapi dengan surat izin praktik yang legalitasnya disahkan oleh pemerintah, sehingga terjadi hal-hal yang tidak diharapkan konsumen mendapatkan kepastian perundangsn.

\section{DAFTAR PUSTAKA}

Agung, K. H. 2006. Analisis Pengaruh Kualitas Layanan, Komitmen, dan Kepercayaan terhadap Loyalitas Konsumen. Tesis. Fakultas Ekonomi Bisnis Universitas Diponegoro. Semarang.

Arikunto, S. 2009. Prosedur Penelitian Suatu Pendekatan Praktik. Edisi Revisi Ke enam. Jakarta: Rineka Cipta.

Budiman, A . 2006. Studi Kualitas Produk Terhadap Loyalitas Pelanggan Studi Kasus di PT. Badranaya Putra. Skripsi. Fakultas Teknologi Pertanian. Bogor.

Erha Clinic Malang. www.erha.co.id. Fauzi'ah, S. 2014. Pengaruh Kualitas Produk Terhadap Loyalitas Pelanggan Dengan
Kepuasan Sebagai Variabel Moderasi. Skripsi. Manajemen Universitas Muhammadiyah . Surakarta.

Ghozali, I. 2001. Aplikasi Analisis Multivariate dengan program SPSS. Semarang: Badan Penerbit Universitas Diponegoro.

.2005. Aplikasi Analisis Multivariate dengan program SPSS. Semarang: Badan Penerbit Universitas Diponegoro

Griffin, J. 2003. Customer Loyalty: Menumbuhkan dan Mempertahankan Pelanggan. Jakarta: Airlangga.

Hadiyati, E. 2010. Analisis Kualitas Pelayanan dan Pengaruhnya Terhadap Loyalitas Pelanggan. Jurnal Manajemen Pemasaran Modern. Vol. 2, No. 2, hlm: 8190.

Hasan, A. 2009. Marketing. Edisi Baru . Yogyakarta: Media pressindo, Hidayat, R. 2009. Pengaruh kualitas layanan, kualitas produk, dan nilai nasabah terhadap kepuasan dan loyalitas pelanggan. Jurnal Manajemen dan Kewirausahaan, Vol. 11, No.1, hlm: 59-72.

Kalalo, Rinny E. 2013. Customer Relationship Management dan Kualitas Pelayanan Pengaruhnya Terhadap Loyalitas Konsumen. Jurnal EMBA. Vol. 1, No. 4, hlm:1553-1561.

Koran Opini. 2015. Inilah 3 Besar Klinik Kecantikan dan Estetika di Surabaya. 18 Januari. http://www.koranopini.com/sand rela/dunia-wanita/3181.[diakses pada 1 April 2016]. 
Kotler, P. 2006. Manajemen Pemasaran. Edisi Kesebelas. Jilid kedua. Jakarta: PT indeks . 2009. Manajemen Pemasaran . Edisi Ketiga belas. Jilid kesatu. Jakarta: Erlangga.

Kotler, P., \& G. Amstrong. 2001. Prinsip-Prinsip Pemasaran. Edisi Kedelapan, Jilid kesatu, Jakarta : Erlangga. . 2008. Prinsip- prinsip pemasaran. Jilid kesatu. Jakarta: Erlangga.

Lovelock, C., \& L.K.Wright. 2007. Manajemen Pemasaran Jasa, PT. Indeks, Indonesia .

Mowen, J.C., \& M. Minor. 2002. Perilaku Konsumen. Jakarta: Erlangga.

Pratiwi, D. I. 2010. Analisis Pengaruh Harapan Pelanggan, Kualitas Produk, Kepuasan Pelanggan Terhadap Loyalitas Pelanggan Internet Flash Unlimited. Skripsi. Fakultas Ekonomi Universitas Diponegoro. Semarang.

Renny Y. Adystiani. 2011. Riset membuktikan Penuaan Kulit Dimulai dari Usia 20-an. 15 Agustus.

http://archive.tabloidbintang.co m/gaya-hidup/cantik-asehat/15042-riset-membuktikanpenuaan-kulit-dimulai-dari-usia20-an.html. [diakses pada 1 April 2016]

Riana, G. 2008. Pengaruh trust in a brand terhadap brand loyalty. Buletin studi ekonomi, Vol. 13, No. 2, hlm: 184-202.

Robbins, Stephen P. 2006. Perilaku Organisasi. Edisi kesepuluh. Jakarta: PT Indeks Kelompok Gramedia.
Setiawan, M.B \& Ukudi .2007. Pengaruh Kualitas Layanan, Kepercayaan Dan Komitmen Terhadap Loyalitas Nasabah. Jurnal Bisnis dan Ekonomi, Vol. 14, No. 2, hlm: 215-227.

Singarimbun, M \& Effendi, S. 1989. Metode Penelitian Survai. Jakarta: LP3ES.

Soegoto, H. 2011. Pengaruh Nilai dan Kepercayaan terhadap Loyalitas Nasabah Prioritas. Majalah ilmiah unikom. Vol. 07, No. 02, hlm: 269-279. Universitas Komputer Indonesia. Sugiyono. 2005. Memahami Penelitian Kualitatif. Bandung: Alfabeta. 2010. Metode Penelitian Kuantitatif Kualitatif dan $R \& D$. Bandung: Alfabeta ...2012. Metode Penelitian Kuantitatif Kualitatif dan $R \& D$. Bandung: Alfabeta.

Tjiptono, F. 2008. Manajemen Jasa. Yogyakarta: Andi .

Tjiptono, F., \& G. Chandra. 2005. Service, Quality \& Satisfication. Yogyakarta: Andi. .2012. Pemasaran Strategik. Yogyakarta. Andi.

Wiyono, G. 2011. Merancang Penelitian Bisnis Dengan Alat Analisis SPSS 17.0 \& SmartPLS 2.0 . Yogyakarta: UPP STIM YKPN.

Yin, Yee \& T.M. Faziharudean.2010. Factors Affecting Customer Loyalty of Using Internet Banking in Malaysia. Journal of Electronic Banking Systems Faculty of Business and Accountancy. University of Malaya. 